\title{
Factors Of National Health Insurance, Factors Of Health Service And Factors Of Social Security Administrator Influence On The Satisfaction Of Independent BPJS Class One At Kertha Usada General Hospital
}

Aditha Angga Pratama
Magister of Public Health Program of
Institut Ilmu Kesehatan STRADA
Indonesia
Email:
pratamaaditha@gmail.com

Received : October 12, 2019

Accepted : February 13, 2020

Published : May 12, 2020

\begin{abstract}
Since 2004 Indonesia has campaigned for universal coverage as one of the improvements in health status. But until now there are still many Health insurance organizer (BPJS) participants who feel unsatisfied with the services they get, especially when Health insurance organizer participants are self-employed in class I inpatient services. The goal of this study is to identify the most dominant factor that can affect the satisfaction of Health insurance organizer participants' services in Kertha Usadha. The cross sectional survey research was conducted on 104 class 1 independent Health insurance organizer participants by simple random sampling. The selected Health insurance organizer participants were interviewed while in a state of hospitalization that was adjusted to the inclusion criteria of this study. The instrument used a structured questionnaire, with several related variables: characteristics, National Health Insurance factors, Health insurance organizer and health services. Variables were analyzed using Chi Square and then Logistic Regression with software. The results of this study found that $54.8 \%$ of B Health insurance organizer participants were satisfied with the services provided. While the results of multivariate analysis found that the factors influencing the satisfaction of Health insurance organizer participants were the National Health Insurance Factors that were good to moderate services (AOR: 1.2, 95\% CI 0.8-1.43), good to less services (AOR: 3.4, 95\% CI 1.5-7.53) and health service factors (AOR: 9.6, 95\% CI 2.37-39.3). Health insurance organizer participant satisfaction is still low so it needs improvement in everything. So that later with increased satisfaction can improve the degree of public health
\end{abstract}

Keywords: National Health Insurance Factors, Health Services, BPJS, Mandiri, Satisfaction

\section{cc) (†) (?)}

This is an open-acces article distributed under the terms of the Creative Commons Attribution-ShareAlike 4.0 International License. 


\section{INTRODUCTION}

Health services are all efforts that are formed both personally and collectively by an organization as an effort to improve health, prevent, and cure from an illness and to restore the health of a person, family, or the wider community. The problem that often arises in general is that places that are expected to provide good and professional health services have not been able to provide what is expected by users of health services.

Since 2004 the National Social Security System (SJSN) mandates that social security for all Indonesian citizens (Universal Coverage) through the Social Security Organizing Agency (BPJS). With the realization of the BPJS, every person who has paid will get services based on the principle of social insurance (Law of the Republic of Indonesia, 2004). Health insurance in Indonesia to date has reached 52.3\% in 2013 (Ministry of Health Republic of Indonesia, 2013). Judging by BPJS user data in 2018 amounted to $81.8 \%$, this has increased even though it is still $13.2 \%$ adrift of the government's target (Tempo, 2019).

There are data on participants from the JKN program in Indonesia as of March 1, 2017 totaling $174,613,853$ people (BPJS, 2014a). While data on the number of BPJS participants in East Java until 2016 found that 22,600,110 participants registered, with the following details that the number of participants consisted of several groups, namely: 1.) National Recipient Assistance (PBI) Recipients, totaling 14,961 .093 people; 2.) Regional PBI, totaling 522,843 people; 3.) Social health insurance (ASKES), as many as 2,228,359 people; 4.) Membership of the TNI and Polri, as many as 391,282 people; 5.) Private workers and Foreign Citizens (foreigners), as many as 2,677,440 people; 6.) Independent or individual workers, 1,819,093 people.

In implementing the JKN system in Indonesia, the Health Social Security Organizing Agency (BPJS Kesehatan) was formed, which in providing BPJS Health services in collaboration with existing health facilities throughout Indonesia (the Indonesian Ministry of Health, 2011). The duties and responsibilities of the BPJS are to ensure health insurance for all Indonesian people can run as a participant of health insurance properly and correctly (Ministry of Health of the Republic of Indonesia, 2011). Whereas at BPJS employment has programs for work accident insurance, old age savings, pension insurance, and death insurance, therefore it is expected that the coverage of the coverage of social security programs can be made in stages.

Presidential Regulation No. 12/2013 states that JKN participants have several categories, namely, BPJS that receive contribution assistance (PBI), Non-PBI BPJS (Not Recipient of Aid Contributions), which are further divided into three groups, namely Wage Recipient Workers (PPU), Non-Workers Wage Recipients (PBPU), Non-Worker BPJS (BP). What the participants said were not wage earners (PBPU) were workers outside the employment relationship or self-employed workers, but non-wage recipient workers including foreign nationals working in Indonesia for a minimum of 6 months. For residents as non-wage earners (PBPU) must be BPJS Mandiri participants, by registering themselves and their family members to the BPJS office as independent BPJS participants, or individuals. Independent BPJS participants must bear the monthly BPJS contributions themselves by each participant concerned, the size of which is in accordance with the BPJS class taken by the participant.

The increase in JKN membership in the field shows something that is inversely proportional to the compliance of payment of contributions. Some factors that influence compliance with national health insurance payments are education, income and the number of family members (Putri, 2017). Besides other factors that influence compliance in payment are the level of knowledge, history of catastrophic diseases, income (Efriyani, 2017).

BPJS Mandiri participants are participants who independently registered themselves at BPJS to get maximum health services. Satisfaction is the need of all health insurance participants. Literally BPJS is a universal coverage that automatically requires all people to use BPJS. The government generally wants to achieve maximum health distribution, but what the community feels is the boundaries that create injustice so that this causes the quality of services obtained to be unsatisfactory (Tjiptoherijanto \& Soesetyo, 2008).

Dissatisfaction that occurs will have an impact on the community's distrust of BPJS and broadly affects the laziness of BPJS participants to return to pay their contributions. The results of previous studies also found that BPJS Mandiri participants responded negatively to the amount of the fees they 
paid. But when you need health services the quality of services provided is not in accordance with the payment made (Pasaribu, 2016).

Currently Kertha Usada Hospital is a referral hospital for all health services both chronic and acute and infectious diseases. Kertha Usada Hospital is a hospital that serves BPJS both BPJS Health and Employment. In this hospital there are also a number of nurses and the finance department who are familiar with BPJS claims. So this place is very scientific for this research. The results of the initial preliminary study found that as many as $63.3 \%$ of BPJS participants who were hospitalized reported that they were not satisfied with the services provided during treatment. So with this background the researcher wants to find factors that are related to BPJS patient satisfaction in class 1 in Kertha Usada General Hospital. Based on this background, researchers are interested in analyzing and researching about the most dominant factors related to the satisfaction of Class 1 BPJS participants.

\section{METHODS}

This type of research is quantitative research with the design of this study using cross sectional observation. The number of samples taken after the sampling formula was 104 respondents with simple random sampling. The independent variable is the JKN participant factor, the health service factor, and the health BPJS factor. The dependent variable is satisfaction The instrument used in this study was a questionnaire with a total of 47 questions that had done validity and reliability. The analysis used in this study is ordinal regression.

\section{RESULTS}

\section{Description of Place of Study}

The demographic characteristics of respondents in this study varied starting from participants who were young and old aged BPJS class 1 users. Before conducting research, researchers have made adjustments to the inclusion and exclusion criteria so that respondents who do not fit into the criteria can be excluded from the sample. The results of the descriptive analysis of characteristic frequencies are found in the following table:

Table 1 Descriptive Analysis of Frequency Characteristics of Respondents

\begin{tabular}{ll}
\hline Variable & $\mathrm{f}(\%)$ \\
\hline Age (Mean \pm SD) & $39,6 \pm 9,6$ \\
Gender & $49(47,6)$ \\
Male & $54(51,9)$ \\
Female & \\
\hline Education level & $3(2,9)$ \\
Basic education & $40(38,5)$ \\
Diploma & $48(46,2)$ \\
Bachelor & $13(12,5)$ \\
Post Graduated & \\
\hline National Health Insurance Factor & $40(38,5)$ \\
Well & $48(46,2)$ \\
Is & $16(15,4)$ \\
Less & \\
\hline Health Service Factor & $40(38,5)$ \\
Well & $64(61,5)$ \\
Is & \\
BPJS Factor & $34(32,7)$ \\
Well & $44(42,3)$ \\
Is & $26(25,0)$ \\
Less & \\
\hline Satisfaction & $57(54,8)$ \\
Satisfied & $47(45,2)$ \\
No &
\end{tabular}


The results reported in Table 1 show that the average age of respondents in this study is in the range of 40 years. Most respondents in this study were female, amounting to $52.4 \%$. Then the most recent education was bachelor as much as $46.2 \%$. Univariate analysis results found that the majority of respondents reported based on the national health insurance factor with a moderate proportion $(46.2 \%)$, the health service factor with the largest proportion was moderate $(61.5 \%)$ while for the BPJS factor the majority also reported moderate $(42,3 \%)$ for those obtained during inpatient care as BPJS Mandiri class 1 patients. While the results of an univariate analysis found that the majority of respondents expressed satisfaction with the services provided at Kertha Usada Hospital when hospitalized, amounting to $54.8 \%$.

\section{The Influence of JKN Factors on Satisfaction of BPJS Participants}

Univariate analysis results on national health insurance factors. Participants reported that the majority of national health insurance received was moderate. Bivariate analysis results are reported in Table 2 below.

Table 2 Effects of BPJS Participant Factors on BPJS Participant Satisfaction

\begin{tabular}{|c|c|c|c|}
\hline \multirow[t]{2}{*}{ Variable } & \multicolumn{2}{|c|}{ Satisfaction } & \multirow[t]{2}{*}{ P Value } \\
\hline & Satisfied & No & \\
\hline \multicolumn{4}{|l|}{ JKN Factor } \\
\hline Well & $18(45,0)$ & $22(55,0)$ & 0,014 \\
\hline Is & $25(52,1)$ & $23(47,9)$ & \\
\hline Less & $14(87,5)$ & $2(12,5)$ & \\
\hline
\end{tabular}

The results of the bivariate analysis in table 2 reported that BPJS participants who reported a good JKN factor as much as $45 \%$ expressed satisfaction and as many as 55\% expressed dissatisfaction. While those who reported that the JKN factor received moderate were 25 people $(52.1 \%)$ expressed satisfaction with BPJS and as many as 23 people $(47.9 \%)$ were not satisfied. These results are bivariate significantly seen from the $\mathrm{p}$ value $<0.05$. These results also indicate that the JKN variable can be entered into a multivariate model assuming a value of $\mathrm{p}<0.05$.

\section{The Influence of Health Service Factors on BPJS Participant Satisfaction}

Factors analyzed bivariate other than the national health insurance factor are BPJS service factors. Bivariate analysis results are found in table 3 below.

Table 3 Effects of BPJS Health Service Factors on BPJS Participant Satisfaction

\begin{tabular}{llll}
\hline \multirow{2}{*}{ Variabel } & \multicolumn{2}{c}{ Satisfaction } & Nilai p \\
\cline { 2 - 3 } & \multicolumn{2}{c}{ Satisfied } & No \\
\hline Health Service Factor & $28(70,0)$ & $12(30,0)$ & \multirow{2}{*}{0,014} \\
Well & $29(45,3)$ & $35(54,7)$ & \\
Is & & \\
\hline
\end{tabular}

Table 3 above reports the results bivariately using chi square. The results of the health service factor found that BPJS participants who reported that good health services were $70 \%$ satisfied with the services provided and only $30 \%$ were not satisfied. This result is also bivariate significant with a p value $<0.05$. So that health service factors can enter the multivariate analysis model.

\section{The Effect of BPJS Factors on the Satisfaction of BPJS Participants}

The BPJS factor is also analyzed bivariately to see the results of the $p$ value, the significance of the effect is bivariate and determines whether or not this variable can be included in multivariate analysis. The results of BPJS factor analysis on satisfaction can be found in table 4 below. 
Table 4 Effect of BPJS Participant Factors on BPJS Participant Satisfaction

\begin{tabular}{llll}
\hline \multirow{2}{*}{ Variable } & \multicolumn{2}{c}{ Satisfaction } & \multirow{2}{*}{ Nilai p } \\
\cline { 2 - 3 } & Satisfied & No & \\
\hline BPJS Factor & & & \\
Well & $21(61,8)$ & $13(38,2)$ & $<0,0001$ \\
Is & $31(60,5)$ & $13(29,5)$ & \\
Less & $15(19,2)$ & $21(80,8)$ & \\
\hline
\end{tabular}

Table 4 above is a bivariate analysis on BPJS factors. It was found that the BPJS Factor was also significantly bivariate with the result that participants who reported the BPJS factor as good as $61.8 \%$ were satisfied with the services provided while only $38.2 \%$ who reported were dissatisfied. This result is significant with; $\mathrm{p}$ value $<0.0001$ which means this factor can be entered into multivariate analysis.

\section{The Most Dominant Factors Influence the Satisfaction of BPJS Participants}

After a bivariate analysis, a multivariate analysis is then performed to see the adjusted odd ratio of each factor which is significantly bivariate. Multivariate analysis used was the logistic regression method of enter. The results of multivariate analysis are found in the following table 5:

Table 5 The most dominant variables affecting BPJS satisfaction

\begin{tabular}{|c|c|c|c|c|}
\hline \multirow{2}{*}{ Variable } & \multirow{2}{*}{ AOR } & \multirow{2}{*}{$\mathrm{p}$ value } & \multicolumn{2}{|c|}{$95 \% \mathrm{CI}$} \\
\hline & & & Lower & Upper \\
\hline \multicolumn{5}{|l|}{ JKN Factor } \\
\hline Well & Reff & & & \\
\hline Is & 1,2 & 0,002 & 0,8 & 1,43 \\
\hline Less & 3,4 & 0,002 & 1,5 & 7,53 \\
\hline \multicolumn{5}{|l|}{ Health Service Factor } \\
\hline Well & Reff & & & \\
\hline Is & 9,6 & 0,002 & 2,37 & 39,3 \\
\hline \multicolumn{5}{|l|}{ BPJS Factor } \\
\hline Well & Reff & & & \\
\hline Is & 1,6 & 0,6 & 0,22 & 1,98 \\
\hline Less & 8,8 & 8,8 & 2,24 & 35,1 \\
\hline
\end{tabular}

The results of the multivariate analysis found that the JKN factor with a good proportion compared to being increased the chances of 1 time the participants get satisfaction in BPJS services (AOR: 1.2, 95\% CI 0.8-1.43). Whereas if the JKN factor obtained is good compared to the less one will increase 3 times the chance of participants getting satisfaction in BPJS services (AOR: 3.4, 95\% CI 1.57.53). While seen from the factor of good health service, there is a 9 times chance to increase satisfaction compared to moderate health service (AOR: 9.6, 95\% CI 2.37-39.3). Judging from the good BPJS factors compared to those who are likely to 1.6 times increase the satisfaction of BPJS participants (AOR: 1.6, 95\% CI 0.22-1.98) so too if the good BPJS factor compared with less than 8 times the opportunity further enhance BPJS participant satisfaction in obtaining services (AOR: 8.8, 95\% CI 2.2435.1). However, this BPJS factor is not dominantly related because the $\mathrm{p}$ value $<0.05$.

\section{DISCUSSION}

\section{Characteristics of Respondents}

Characteristics of respondents in this study varied from the age of the respondent, work to the last education. These results found that the average age of BPJS participants was in the age range of 40 years. These results are in line with research conducted at Sumenep that most of the BPJS class 1 participants are in the age range> 40 years (Rindi Antina, 2016). In general the characteristics of respondents are very influential in all behavioral behavior. Younger people are usually more sensitive and open to express dissatisfaction with a service (Sitompul, 2012). 
Another result related to characteristics is the last education of the respondents. Most of the last educated as bachelor because BPJS participants are independent participants who pay contributions independently each month. The same results from previous studies found different things that the last education was only in high school (Farianita, 2016). In highly educated respondents the way of thinking of respondents is more critical, more informative and expects more in a service especially in the form of services. While those with low education usually accept more of the services provided (Farianita, 2016)

These results also found that the majority of BPJS participants were female. Similar results were also found in Semarang that the majority of respondents were women (Farianita, 2016). The sexes of women tend to be more satisfied with the services provided than men. Male gender tends to be dominant, active and free shown by the nature of confidence, frankly, competitive and confident. Whereas female gender tends to be sensitive in formal relationships which are shown by being understanding, warm, wise and can work together patiently (Sitompul, 2012). Gender greatly influences the view of a service rendered. Women are more detailed in assessing a thing (Oroh, 2012).

\section{JKN Factors Influence the Satisfaction of Class 1 Independent BPJS Participants}

A good quality of service, it will directly increase patient satisfaction. Satisfaction is measured by five tangible dimensions, reliability, responsiveness, assurance and empathy. So if the five dimensions of service quality can be carried out optimally by the health service provider, it will manifest maximum patient satisfaction. in general it is formulated that the limits of quality health services are health services that can satisfy each service user in accordance with the average level of satisfaction of the population and its implementation in accordance with established codes of ethics and standards. The quality of health services in hospitals is a unique phenomenon because the dimensions and indicators can be different for people involved in health care (Azwar, 2005).

Several factors related to increasing service satisfaction of BPJS participants, one of which is the JKN factor. As for the JKN factor in the form of information obtained, social support, knowledge and family support. Some programs carried out by BPJS are solely to improve services that result in BPJS participant satisfaction. From the side of BPJS officers also already feel that they provide the maximum service. There are already several things that are felt to be helpful, such as the flow of services which, although divided, there are still advantages in itself, doctors also always help provide complete information to patients so that the BPJS section can more easily carry out its duties, hospital management is also cooperative, and the room given is also sufficient. Although, there are still shortcomings such as the lack of a bridging system, so officers still have to work twice because patient data from registration cannot be directly connected to the BPJS section. In terms of human resources, service to patients is still considered inadequate to compensate for the large number of patients and the existing facilities are still slightly inadequate to work fast. But there are still things that can reduce the level of trust of BPJS participants. A good perception of the facilities in a hospital outpatient installation will lead to satisfaction, trust, and expectations in patients, then determine the attitudes and subsequent behavior towards hospital services. Hospital BPJS participant satisfaction that accumulates continuously will lead to a positive attitude (Nugroho, 2011).

\section{Health Service Factors Influence the Satisfaction of Class I BPJS Participants}

In addition to the JKN factor, the dominant factor influencing the satisfaction of BPJS Mandiri Class I participants was health care. In terms of service quality with measuring tools in the form of medical personnel, health facilities, imagery, easy access and visual design found to be related to BPJS participant satisfaction. This result, of course, starts from the hospital trying to give the best, both in terms of medical services and administrative services. This can be seen from the results of the study, where as a provider of medical services namely doctors, and administrative service providers namely BPJS officers have provided the best service they can provide. Although in some cases there are still some shortcomings for example in terms of infrastructure tools or facilities, then the existing system, and human resources are still lacking in quantity. However, many things are felt by medical staff to be optimal in terms of providing optimal services, such as the same service procedures according to standard operational procedures for both BPJS patients or not, information, promotive efforts, and patient education, good communication and providing time for patients. In terms of space and facilities were deemed adequate, although there are still some that are lacking, but still not too inhibiting to 
provide optimal service. Deficiencies felt by medical staff, especially in terms of diagnostic support, some inspection tools that are still incomplete, and existing tools but the quality is not good so that sometimes somewhat hinder the performance of medical personnel. Maybe it should be from the hospital itself trying to complement the equipment that does not yet exist and improve the quality of existing equipment. The quality of service which is considered good and reliable makes the service recipients trust and put greater expectations on the service providers (Tjiptono, 2014).

Pharmaceutical services are also very important in increasing the satisfaction of BPJS participants. Good perception of drug services (pharmacies) in hospital outpatient installations will lead to satisfaction, trust, and expectations in patients, then determine the attitudes and behaviors towards hospital services. Hospital BPJS participant satisfaction that accumulates continuously will lead to a positive attitude (Firdaus \& Dewi, 2015). Very many factors that support BPJS satisfaction can be achieved.

\section{BPJS Factors Have No Effect on Satisfaction of Class I Independent BPJS Participants}

The results of this study instead found that the BPJS factor was not related to BPJS participant satisfaction. The BPJS factors include the characteristics of service products, administrative management and prices, health service procedures and complaint handling. This result is not related to patient satisfaction. Matters relating to satisfaction with meeting one's needs are relative. As we know that humans are creatures that continuously have desires, as soon as certain needs are met then other needs arise. Humans are continuously making efforts to satisfy their needs (Maricq, 2012). These needs will affect the behavior of patients who are basically consumers of health services. Patients are directly involved in obtaining and using goods or services, including in the decision making process in the preparation and determination of an activity (Bambang, 2010). The assurance factor (assurance) is the knowledge, courtesy and ability of medical staff to generate patient confidence and confidence in the hospital (Fais, 2014).

\section{CONCLUSION}

There is an Effect of JKN Factors on Bivariate Class I BPJS Mandiri Participant Satisfaction. There is an Influence of BPJS Factors on the Satisfaction of Class I Independent BPJS Participants. There is an Influence of Health Service Factors on bivariate BPJS Mandiri Class I Participant Satisfaction. The most dominant factors that influence multivariately are JKN and health services

\section{REFERENCES}

Asnawi, F. (2009). Dalam jurnal Peningkatan Kemampuan Membaca Pemahaman Melalui Penerapan

Teknik Skema. Retrieved from http:///Pakguruonlinependidikan.net/actronreseach.html

Azwar, S. (2005). Reliabilitas dan Validitas: Seri Pengukuran Psikologi. Sigma.

Bambang, H. (2010). Manajemen Pemasaran Untuk Rumah Sakit. Jakarta: Rineka Cipta.

BPJS. (2014a). Panduan Praktis Rujukan Berjenjang. Jakarta.

BPJS. (2014b). Panduan Praktis Sistem Rujukan Berjenjang. Jakarta.

Claycomb, C., \& Martin, C. . (2002). Building Customer Relationships: An Inventory of Service Providers, Objectives and Practices. The Journal of Services Marketing, 16 No.7, 615-635.

CM Hutabarat. (2013). Gambaran Kepuasan Pasien Pengguna Kartu Jakarta Sehat di Unit Rawat Jalan RSU UKI Tahun 2013. Universitas Indonesia.

Darmawi, H. (2010). Manajemen Asuransi. Jakarta: Bumi Aksara.

Delamater, A. . (2006). Improving Patient Adherence. Clinical Diabetes, 24 No.2, 71-77.

Departemen Kesehatan RI. (2011). Peraturan Menteri Kesehatan Republik Indonesia Nomor 1171/MENKES/PER/III/2011 Tentang Sistem Informasi Rumah Sakit. Jakarta.

Efriyani, R. (2017). Faktor-Faktor yang Berhubungan dengan Kepatuhan Peserta Mandiri dalam Membayar Iuran Jaminan Kesehatan Nasional di Kelurahan Lubuk Buaya Tahun 2017. Jurnal Universitas Andalas.

Fais, M. (2014). Organisasi dan Manajemen Pelayanan Kesehatan. Jakarta Selatan: Salemba Medika. Farianita, R. (2016). Faktor-Faktor Yang Berhubungan dengan Kepuasan Peserta BPJS Terhadap Pelayanan Instalasi Rawat Jalan di Rumah Sakit Tk. III Bhakti Wira Tamtama Semarang.

Firdaus, F., \& Dewi, A. (2015). Evaluasi Kualitas Pelayanan Terhadap Kepuasan Pasien Rawat Jalan Peserta BPJS di RSUD Panembahan Senopati Bantul. Program Studi Manajemen Rumah Sakit 
Universitas Muhammadiyah Yogyakarta.

Fitriani. (2009). Efektivitas Latihan Kultivasi (Falun Dafa) Terhadap Penurunan Tekanan Darah pada Penderita Hipertensi di Dusun X Desa Buntu Bedimbar Kecamatan Tanjung Morawa Kabupaten Deli Serdang. Universitas Sumatra Utara.

Handini, I. (2015). Customer GAP Pelayanan BPJS Kesehatan Center. Universitas Airlangga.

Hutabarat, C. . (2013). Gambaran Kepuasan Pasien Pengguna Kartu Jakarta Sehat di Unit Rawat Jalan RSU UKI Tahun 2013. Universitas Indonesia.

Irawan, H. (2008). 10 Prinsip Kepuasan Pelanggan. Jakarta: Elex Media Komputindo.

Juran, J. (2008). Juran's Quality Control Handbook 1\&2 (4th ed.). Mc Grawhill Inc.

Kemenkes RI. (2011). Buku Pedoman Nasional Pengendalian Tuberkolusis. Jakarta.

Kemenkes RI. (2013). Riset Kesehatan Dasar. Jakarta.

Kemenkes RI. (2014). Buku Pegangan Sosialisasi Jaminan Kesehatan Nasional Dalam Sistem Jaminan Nasional Jilid 1. Jakarta.

Kotler, P. (2012). Manajemen Pemasaran (Edisi Milenium). Jakarta: PT Indeks Kelompok Gramedia.

Kotler, P. (2015). Manajemen Pemasaran (Edisi Melinium). Jakarta: Prenhallindo.

Kotler, P., \& Armstrong, G. (2010). Principles of Marketing (edisi 13). United States: Pearson.

Lupiyoadi. (2008). Manajemen Pemasaran Jasa Edisi Ke-3. Jakarta: Salemba Empat.

Maricq, H. . et al. (2012). Prevalence Of Scleroderma Spectrum Disorders In The General Population.

Nugroho, S. (2011). Analisis Mutu Pelayanan Terhadap Kepuasan Pasien Umum Di Balai Pengobatan Umum Puskesmas Wonopringgo Kabupaten Pekalongan. Semarang.

Oroh, M. (2012). Faktor-Faktor Yang Berhubungan Dengan Tingkat Kepuasan Pasien Rawat Inap Terhadap Pelayanan Keperawatan Di Ruang Interna RSUD Noongan. Manado.

Pasaribu, K. F. (2016). Respon peserta BPJS kesehatan mandiri tentang besaran iuaran dan keberlanjutan kepesertaan di kecamatan medan perjuangan kota medan tahun2016. Universitas Sumatera Utara, 90.

Putri, D. (2017). Faktor-Faktor yang Berhubungan dengan Kepatuhan Peserta Mandiri dalam Membayar Iuran Jaminan Kesehatan Nasional di Kota Padang Tahun 2016. Jurnal Universitas Andalas.

Rangkuti, F. (2013). Teknik Mengukur dan Strategi Meningkatkan Kepuasan Konsumen. PT. Gramedia Pustaka.

Rindi Antina, R. (2016). Analisis Kualitas Pelayanan Terhadap Kepuasan Pasien Peserta Bpjs Di Puskesmas Pandian Kabupaten Sumenep. JPAP: Jurnal Penelitian Administrasi Publik, 2(02), 567-576. https://doi.org/10.30996/jpap.v2i02.1010

Sitompul, J. (2012). Faktor-Faktor Yang Berhubungan Dengan Kepuasan Peserta Askes Sosial Terhadap Pelayanan Askes Center Di Rs. Depati Hamzah Pangkalpinang. Jakarta.

Subekti. (2015). Pokok-Pokok Hukum Perdata. Jakarta: PT Intermasa.

Sugiyono. (2008). Metode Penelitian Pendidikan Pendekatan Kuantitatif, Kualitatif dan $R \& D$. Bandung: Alfabeta.

Tempo. (2019). Peserta BPJS Kesehatan Capai 81,8 Persen Penduduk Indonesia.

Tjiptoherijanto, P., \& Soesetyo, B. (2008). Ekonomi Kesehatan. Jakarta: Rineka Cipta.

Tjiptono, A. (2014). Pemasaran Jasa. Yogyakarta.

Tjiptono, F. (2010). Manajemen jasa (Ed.1). Yogyakarta: PT Indeks Kelompok Gramedia.

UU Republik Indonesia. Undang-Undang No.40 Tahun 2004 tentang Sistem Jaminan Sosial Nasional (SJSN). , (2004).

Wijono, D. (2008). Manajemen Puskesmas-Kebijakan dan Strategi. Surabaya: CV Duta Prima Airlangga.

Yulianti. (2013). Analisis Kepuasan Unit Rawat Jalan Rumah Sakit Bhakti Yudha Depok Tahun 2012. Universitas Indonesia.

Yustisianto, J. (2009). Kualitas Pelayanan Kesehatan Puskesmas Kecamatan Gambir Jakarta Pusat. Universitas Indonesia. 